\title{
Проблемы отмены смертной казни в России в контексте международных обязательств
}

\author{
Иванов А. В., \\ адвокат \\ (Краснодарская коллегия адвокатов) \\ e-mail: advocatkk@gmail.com
}

\begin{abstract}
Аннотация. Проблемы применения смертной казни как исключительной меры наказания, ее соотношения с правом на жизнь давно являются объектом общественного обсуждения и актуальными для каждого изиилизованного государства. В международном праве установлен запрет на применение смертной казни, поскольку ее применение противоречит основному принципу уважения прав и основных свобод человека, а также признанию абсолютного права на жизнь.

Одним из существенных условий для приглашения Российской Федерации (далее - России) в Совет Европы было условие отмены смертной казни, однако Россия до сих пор не ратифицировала Протокол № 6, не предприняла действий, направленных на абсолютный отказ от смертной казни, поэтому проблема смертной казни и возможности ее применения как вида уголовного наказания продолжает сохранять свою актуальность.

Ключевье слова: право на жизнь, смертная казнь, преступление, уголовное наказание, международные обязательства, отмена смертной казни, мораторий, ратификаиия, Протокол № 6, Протокол № 13, Второй факультативный протокол к Международному пакту о гражданских и политических правах.
\end{abstract}

$\Pi$ роблема смертной казни является остродискуссионной, многоаспектной и давно привлекает внимание не только ученых и специалистов в области права, но и философов, политологов, социологов, политических и общественных деятелей.

В обществе отсутствует единое мнение по поводу смертной казни, поскольку она затрагивает не только правовые, но и политические, социально-экономические, нравственные, религиозные, культурные, морально-этические и другие сферы общественной деятельности. Ученые и специалисты придерживаются разных точек зрения относительно смертной казни как вида уголовного наказания, так и правомерности ее неприменения и отмены.

Сторонники смертной казни считают, что она позволяет противодействовать росту преступности и способствует восстановлению социальной справедливости.

«Убийца заслуживает смертной казни даже в том случае, если его можно исправить, ибо смертная казнь в этом случае удовлетворяет чувство гнева, с которым население воспринимает совершение этого тяжкого преступления» ${ }^{\text {. }}$

Противники смертной казни выступают за ее отмену, поскольку она фактически не сдерживает преступности, а ее применение является нарушением права человека на жизнь.

Еще в XIX в. Н. Д. Сергеевский пришел к выводу, что «смертная казнь в современном государстве не должна занимать места в лестнице наказаний»². Смертная казнь «отрицает в пре-

\footnotetext{
1 Berns W. For Capital Punishment: Crime and the Morality of the Death Penalty. N.Y., 1979. P. 322.

2 Сергеевский Н. Д. Лишение жизни как уголовное наказание // Юридический вестник. 1879. № 6. С. 848, 850, 857.
}

ступнике человека, лишает его присущего всякому лицу права на существование и нравственное возрождение и делает из него страдательное орудие чужой безопасности».

По мнению В. Н. Кудрявцева, «не может быть никакого нравственного обоснования для расправы с отдельным, уже беззащитным и теперь неопасным человеком, для применения смертной казни к преступнику. Эту меру необходимо исключить из набора криминологических стратегий»

Не вдаваясь в аргументацию сторонников и противников смертной казни, хотелось бы обратить внимание на следующее.

В законодательстве зарубежных стран по-разному регулируется возможность применения смертной казни. Однако в мировом сообществе существует устойчивая и последовательная тенденция, направленная на полную отмену смертной казни, отражающая приверженность гуманистическим ценностям и обусловленная признанием человеческой жизни высшей ценностью.

В 1996 г., с целью влиться в европейское пространство, идти по пути строительства демократических институтов, признания прав и свобод человека в качестве высшей ценности, Россия вступила в Совет Европы, что послужило важной предпосылкой для реформирования правовой системы и изменения законодательства, противоречащего положениям Конвенции о защите прав человека и основных свобод (далее Конвенция). Одними из существенных условий

\footnotetext{
3 Соловьев В. С. Оправдание добра: нравственная философия. М., 1996. С. 292.

4 Кудрявцев В. Н. Стратегии борьбы с преступностью. M., 2005. C. 160 .
} 
вступления были установление моратория на приведение в исполнение приговоров к смертной казни и принятие мер по ее отмене. Россией в течение целого ряда лет проводилась достаточно интенсивная работа по приведению национального законодательства в соответствие с европейскими нормами в области прав человека.

В то же время Протокол № 6 к Конвенции «Относительно отмены смертной казни» (далее Протокол № 6) до настоящего времени Россией не ратифицирован и вопрос по поводу отмены смертной казни как уголовного наказания окончательно не решен, что порождает многочисленные споры, связанные с проблемой надлежащих гарантий неприменения смертной казни.

Как известно, права человека - это ценнейшее достояние любого цивилизованного государства. Право на жизнь является одним из фундаментальных, неотъемлемых, неотчуждаемых и принадлежащих каждому от рождения. Данное право закреплено во многих международных правовых актах (ст. 3 Всеобщей декларации прав человека; Декларация независимости США; ст. 6 Международного пакта о гражданских и политических правах (далее - Пакт); ст. 2 Конвенции о защите прав человека и основных свобод; ст. 2 Конвенции СНГ о правах и основных свободах человека; ст. 4 Американской конвенции о правах человека; ст. 5 Арабской хартии прав человека; ст. 2 Каирской декларации; ст. 2 Хартии основных прав Европейского Союза и др.).

Это право закреплено многими странами на уровне конституций (ст. 28 Конституции Республики Болгария; ст. 2 Основного закона ФРГ; ст. 17 Конституции Португалии; ст. 17 Конституции Республики Словения; ст. 21 Конституции Республики Хорватия; ст. 15 Конституции Словацкой Республики; ст. 6 Конституции Чешской Республики; ст. 40 Конституции Ирландии; ст. 15 Конституции Испании; ст. 20 Конституции РФ и др.).

Таким образом, право на жизнь признано высшей ценностью в демократическом обществе.

Вопросам регламентации права на жизнь уделено значительное внимание в юридической литературе, однако проблемы обеспечения права на жизнь, соотношения права на жизнь и смертной казни, а также пределов применения смертной казни в цивилизованном мире до сих пор находятся в центре научного, общественного и политического внимания.

В цивилизованном мире, где существует баланс между правами человека, интересами общества и государства, давно начало складываться понимание того, что смертная казнь является законной формой убийства, санкционированной государством, что она представляет собой вид уголовного наказания, целью которого является преднамеренное лишение государством челове- ка жизни. По поводу негативных моментов этого вида наказания международным сообеством выработана устойчивая позиция: смертная казнь исключает возможность реабилитации и примирения; провоцирует решение сложных проблем человечества примитивными способами, вместо того чтобы способствовать пониманию их причин и поиску конструктивных подходов; продлевает страдания родственников убитого и причиняет такие же страдания близким осужденного за убийство; требует ресурсов и энергии, которые следовало бы направить на борьбу с насильственными преступлениями и помощь тем, кто от них пострадал; является признаком культуры насилия, а не способом противодействия ему; она оскорбительна для человеческого достоинства.

Согласно мнению В. Е. Квашиса «именно в XX веке было казнено больше людей, чем в любом другом» ${ }^{5}$. Однако на рубеже XXI в. практика применения смертной казни претерпела существенные изменения, в мире наметилась ясная и устойчивая тенденция к отмене смертной казни и ее ограничению.

Впервые в истории смертная казнь была отменена в США в штате Мичиган в 1846 г. В Европе первой сделала такой шаг Португалия в 1867 г.

В 1950 г. Конвенция установила, что никто не может быть намеренно лишен жизни иначе как во исполнение смертного приговора, вынесенного судом за совершение преступления, в отношении которого законом предусмотрено такое наказание.

Европейский суд по правам человека (далее - ЕСПЧ), используя правомочие по системному и эволюционному толкованию норм международного договора, в собственных постановлениях красной линией проводит мысль о том, что ст. 2 Конвенции является основополагающей; она не только предписывает государству воздержаться от умышленного и незаконного лишения жизни, но также обязывает принять меры по защите жизни лиц, находящихся под его юрисдикцией 6 (постановления ЕСПЧ от 09.06.1998 г. ${ }^{7}$, от 28.10.1998 г. ${ }^{8}$, от 10.05.2001 г. ${ }^{9}$; От 20.12.2004 Г. ${ }^{10}$ ).

\footnotetext{
Квашис В. Е. Смертная казнь. Мировые тенденции, проблемы и перспективы. М., 2008. С. 3.

6 Малько А. В., Терехин В. А., Афанасьев С. Ф. Смертная казнь в современной России: не пора ли наконец определиться? // Криминологический журнал БГУЭП. 2014. № 2. С. 81.

7 L.C.В. против Соединенного Королевства: Постановление ЕСПЧ от 09.06.1998 г. // http://www.echr.coe.int.

8 Осман (Osman) против Соединенного Королевства: Постановление ЕСПЧ от 28.10.1998 г. // http://www.echr. coe.int.

9 Кипр против Турции: Постановление ЕСПЧ от 10.05.2001 г. // http://www.echr.coe.int.

10 Макаратзис (Makaratzis) против Греции: Постановление ЕСПЧ от 20.12.2004 г. // http://www.echr.coe.int.
} 
В 1977 г. Генеральная Ассамблея ООН призвала государства к постепенному уменьшению числа преступлений, за которые может быть назначена смертная казнь, с целью ее последующей отмены.

В 1983 г. страны - члены Совета Европы одобрили дополнение Конвенции Протоколом № 6 об отмене смертной казни в мирное время. С 1994 г. одними из условий вступления государств в Совет Европы стали введение ими моратория на приведение смертной казни в исполнение, а также обязательство подписать Протокол № 6 к Конвенции в течение года с момента вступления в Организацию и ратифицировать его в течение трех лет с момента подписания ${ }^{11}$.

Протокол № 6 стал первым международным документом, закрепившим отмену смертной казни в качестве юридического обязательства государства, подписавшего и ратифицировавшего этот акт. В настоящий момент из 47 государств членов Совета Европы только Россия не ратифицировала указанный Протокол.

Резолюцией 44/128 Генеральной Ассамблеи ООН от 15.12.1989 г. принят Второй Факультативный протокол к Пакту, направленный на отмену смертной казни, который подписан уже 78 государствами - участниками Пакта (из 167 стран, присоединившихся к Пакту, и из 140 стран, в которых смертная казнь уже отменена в законе или на практике). Россия в подписании не участвует.

Принятый Генеральной Ассамблеей Организации американских государств в 1990 г. Протокол к Американской конвенции о правах человека об отмене смертной казни ратифицирован 46 государствами.

1 июля 2003 г. вступил в силу Протокол № 13 к Конвенции, не допускающий возможности применения смертной казни во время войны или при неизбежной угрозе войны (ратифицирован 40 государствами - членами Совета Европы). В Преамбуле Протокола № 13 указано, что всеобщее право на жизнь является основной ценностью в демократическом обществе и что отмена смертной казни необходима для защиты этого права, а также для полного признания достоинства, присущего всем людям. Государства-участники, желая усилить защиту права на жизнь, отмечая, что Протокол № 6 не запрещает смертную казнь в отношении участников действий, совершенных во время войны или в условиях неизбежной угрозы войны, решили сделать заключительный шаг к отмене смертной казни при всех обстоятельствах.

Безусловно, данный шаг, направленный на абсолютный запрет применения смертной казни, стоит только приветствовать, поскольку он соот-

11 Сидоркин А. С. Проблема отмены смертной казни сквозь призму общих принципов права // Вестник РУДН. Серия «Юридические науки». 2010. № 4. С. 27-28. ветствует общемировой тенденции и направлен на последовательную реализацию принципа гуманизма. Россия не подписала и не ратифицировала также и этот протокол.

Свидетельством общемировой тенденции, направленной на отмену смертной казни, служит также проведение саммитов Совета Европы, всемирных конгрессов, направленных против смертной казни и на введение моратория на казни в мирное время, а также присоединение государств к международным документам.

В настоящее время смертная казнь не предусмотрена в числе мер наказания Уставом Международного трибунала для бывшей Югославии и Уставом Международного трибунала по Руанде.

На 57-й сессии ПАСЕ было отмечено, что применение смертной казни является нарушением самого главного права человека - права на жизнь. Смертная казнь должна быть полностью и навсегда исключена из законодательства всех государств, выступающих за демократию, верховенство закона и права человека. В рекомендациях, принятых на 57-й сессии, было указано, что ПАСЕ рекомендует Комитету министров Совета Европы обязать Россию незамедлительно ратифицировать Протокол № 6 об отмене смертной казни в мирное время.

Свидетельством тенденций на международном уровне, направленных на отмену смертной казни, служат также принятые Генеральной Ассамблеей ООН резолюции № 62/149 от 18.12.2007 г. № 63/168, от 18.12.2008 г. и 65/206 от 21.12.2010 г. по вопросу о моратории на применение смертной казни, в которых она призвала государства, в которых все еще сохраняется смертная казнь, ввести мораторий на приведение смертных приговоров в исполнение в целях отмены смертной казни.

В Резолюции Генеральной Ассамблеи ООН от 18.12.2007 г. было отмечено, что применение смертной казни подрывает человеческое достоинство. Генеральная Ассамблея ООН призвала государства, где еще сохраняется смертная казнь, ввести мораторий на приведение смертных приговоров в исполнение с целью отмены смертной казни, а государствам, в которых была отменена смертная казнь, не вводить ее вновь.

Абсолютный запрет на применение смертной казни уже признан многими государствами членами ООН, Совета Европы, Европейского союза, ОБСЕ, Организации американских государств. Отмена смертной казни является естественной тенденцией современных демократических государств.

В одних странах она отменена на конституционном уровне (конституции Княжества Андорра, Бельгии, Португальской Республики, Основной закон ФРГ), в других допускается в определенных случаях в мирное время 
(Конституция Азербайджанской Республики) ${ }^{12}$, в военное время или при чрезвычайных обстоятельствах (конституции Аргентины, Бразилии, Великобритании, Израиля, Италии, Испании, Канады, Мексики, Швейцарии).

Около 140 государств отменили смертную казнь (Франция, Чехия, Швеция, Англия ${ }^{13}$ и др.), признавая ее чрезмерно жестоким и диспропорциональным видом наказания, которое отрицает гуманистические ценности и достоинство человека; в иных - всего порядка 58-ми (США, Китай, Индия, Индонезия, Иран, Саудовская Аравия и др.) - она с той или иной степенью регулярности применяется на основе общих и специальных нормативных правовых актов за тяжкие преступления ${ }^{14}$.

Несмотря на то, что законодательство США предусматривает возможность применения смертной казни, в некоторых штатах США (Аризона, Коннектикут, Флорида, Миссури и Северная Каролина) приняты законодательные акты, запрещающие применение смертной казни для умственно отсталых людей, предпринимаются попытки ввести мораторий на смертную казнь. С 2007 г. смертная казнь не применяется в штатах Нью-Джерси, Нью-Йорк, а с 2009 г. в Нью-Мексико. В марте 2011 г. исключительная мера наказания была отменена в штате Иллинойс ${ }^{15}$

В странах среднеазиатского региона (Таджикистан, Киргизия, Узбекистан, Казахстан и др.) смертная казнь как самостоятельная мера карательного воздействия имеет место, но с начала 2000-х г. она повсеместно не применяется по причине введения отсрочки ${ }^{16}$.

По сведениям Amnesty International в 2013 г. смертные приговоры привели в исполнение в 22 странах. В числе стран-лидеров по применению смертной казни находятся Китай, Иран, Ирак, Саудовская Аравия, США и Сомали. Из стран Европы смертную казнь продолжают применять лишь в Белоруссии, которая не является членом Совета Европы ${ }^{17}$.

2 июля 2014 г. Генеральный секретарь ООН Пан Ги Мун заявил о том, что смертной

\footnotetext{
12 Коняев С. А. Мораторий на применение смертной казни в России: конституционно-правовой аспект // Вестник Воронежского государственного университета. Серия «Право». 2011. № 1. С. 74-75.

13 Степенко А. В., Никулина О. А. Исключительные случаи применения смертной казни // Ученые заметки ТОГУ. 2014. T. 5. № 4. С. 406.

14 Назарова Ф. На пути к отмене смертной казни - опыт СНГ и Европейского Союза. Душанбе, 2010. С. 5.

15 Агаев Д. О. Современные тенденции развития института смертной казни // Пробелы в российском законодательстве. 2012. № 1. С. 157.

16 Малько А. В., Терехин В. А., Афанасьев С. Ф. Указ. соч. C. 82 .

17 URL: amnesty.org.ru/smertnaya-kazn-2013
}

казни не должно быть в XXI в., и призвал все государства отказаться от ее применения.

В результате прилагаемых усилий международного сообщества 51 из 56 государств участников ОБСЕ отменили смертную казнь за все виды преступлений. Только в четырех государствах-участниках - Казахстане, Монголии, России и Таджикистане - смертная казнь сохраняется в законодательстве в качестве наказания за преступления, совершенные в мирное время, однако смертные приговоры в исполнение не приводятся. В двух государствах-участниках - Беларуси и США - смертная казнь применятся за преступления, совершенные в мирное время, и смертные приговоры приводятся в исполнение ${ }^{18}$.

Таким образом, смертная казнь является подрывающим человеческое достоинство явлением. В результате усилий мирового сообщества наблюдается устойчивая тенденция к отказу государств от применения смертной казни, в том числе и за международные преступления. Общее количество стран, применяющих смертную казнь, неуклонно сокращается на протяжении последних лет.

Вопрос об отмене смертной казни в России обсуждается давно и относится к наиболее дискуссионным.

Как отмечается в юридической литературе, «в обществе всегда присутствовало весьма неоднозначное отношение к смертной казни. Россия никогда не была страной демократической и, возможно, еще долго не сможет стать правовым государством. Психология десятков поколений людей, проживавших в нашей стране, отмечена жестокостью и насилием» ${ }^{19}$.

Глава СК РФ А. Бастрыкин высказался за сохранение в Уголовном кодексе РФ смертной казни ${ }^{20}$. Во ФСИН, напротив, не поддержали высказанное главой СК РФ предложение 21.

В обществе с богатым тоталитарным наследием, с опытом неэффективной борьбы с преступностью, с масштабными проявлениями национализма, ксенофобии и радикальными идеями вряд ли приходится рассчитывать на широкую поддержку идей гуманизма. Однако и в зарубежных странах отмена смертной казни происходила без поддержки населения, которое впоследствии воспринимало позицию законодателя и разделяло ее. В России же сам законодатель отстаивает идею преждевременности отмены смертной казни.

\footnotetext{
18 Смертная казнь в регионе ОБСЕ: Справочный документ 2013 г.

19 Коновалова Т. Ф. Нужна ли России смертная казнь? // Уголовно-исполнительная система: право, экономика, управление. 2010. № 2. С. 23.

20 URL: lenta.ru/news/2014/05/29/bastrykin/

21 URL: www.newsru.com/russia/30may2014/execution.html
} 
Для выполнения обязательства по ратификации Протокола № 6 в России предпринимались определенные шаги. Указом Президента РФ «О поэтапном сокращении применения смертной казни в связи с вхождением России в Совет Европы» Правительству РФ было поручено подготовить для внесения в Госдуму проект закона о присоединении России к Протоколу № 6 к Конвенции.

27 февраля 1997 г. Президентом РФ было издано Распоряжение «О подписании Протокола № 6 Конвенции», согласно которому Минюст России должен был разработать комплекс мер по поэтапному решению проблем, связанных с ратификацией Протокола, однако Госдума отклонила законопроект о моратории на смертную казнь.

Указом от 03.06.1999 г. № 698 Президентом РФ было помиловано 703 осужденных к смертной казни.

6 августа 1999 г. в Госдуму Президентом РФ был внесен проект закона о ратификации Протокола № 6, предусматривающего внесение изменений и дополнений в законодательство. Как отмечалось в сопроводительном письме к законопроекту, ратификация Протокола подтвердит приверженность России принципам гуманизма, демократии и права, а также будет способствовать осуществлению установленных Конституцией РФ положений, касающихся защиты главного естественного права человека — права на жизнь.

Распоряжением Президента РФ от 28.08.2001 г. № 462-рп были назначены его представители при рассмотрении палатами ФС РФ вопроса о ратификации Протокола № 6. Однако 15 февраля 2002 г. Госдума приняла постановление № 2483-ІІІГД об обращении к Президенту РФ о преждевременности ратификации Протокола № 6.

Таким образом, несмотря на то, что Россией предприняты определенные усилия, направленные на выполнение имеющихся международных обязательств, Протокол № 6 до сих пор не ратифицирован.

Даже после того, как Россия стала членом Совета Европы, российские суды по-прежнему выносили приговоры с назначением наказания в виде смертной казни 22 . Последняя смертная казнь в России была приведена в исполнение 2 сентября 1996 г.

В связи с вступлением России в Совет Европы и невыполнением обязательств по ратификации Протокола № 6 Конституционный Суд РФ

\footnotetext{
22 Работа судов общей юрисдикции в 1999 году // Российская юстиция. 2000. № 7, 8; Работа судов общей юрисдикции в 2000 году // Российская юстиция. 2001. № 11; Постановление Московского городского суда от 11.08.1999 г. по обвинению Г. А.; Постановление Московского городского суда от 05.08.1999 г. по обвинению П. А., Л. Р., Г. В., Ш. А., А. А., Б. М., Т. И., С. С., М. А. и др. // base.consultant.ru.
}

(далее - КС РФ) в 1999 г. принял постановление, в котором провозгласил неконституционность назначения наказания в виде смертной казни до введения в действие федерального закона, обеспечивающего на всей территории России каждому обвиняемому в преступлении, за совершение которого в качестве исключительной меры наказания установлена смертная казнь, право на рассмотрение его дела судом с участием присяжных заседателей (Постановление КС РФ от 02.02.1999 г. № 3-П).

На наш взгляд, в условиях, когда Россия не смогла выполнить принятые международные обязательства, постановление КС РФ является скорее политическим, а не юридическим, продиктованным коньюнктурной избирательностью, имеющим своей целью скорее запрет на назначение наказания в виде смертной казни, нежели обеспечение принципа равноправия и права на рассмотрение дела судом с участием присяжных заседателей.

С введением 1 января 2010 г. суда присяжных на всей территории России и с целью устранения возможной противоречивой правоприменительной практики относительно допустимости назначения смертной казни Верховный Суд РФ обратился с запросом в КС РФ о разъяснении Постановления от 02.02.1999 г. № 3-П.

В Определении от 19.11.2009 г. № 1344-О-Р КС РФ пришел к выводу, что «в России в настоящее время действует конкретизирующий закрепленные Конституцией РФ гарантии права на жизнь комплексный мораторий на применение смертной казни, сформировались устойчивые гарантии права не быть подвергнутым смертной казни и сложился легитимный конституционно-правовой режим, в рамках которого - с учетом международно-правовой тенденции и обязательств, взятых на себя Россией, - происходит необратимый процесс, направленный на отмену смертной казни, т. е. на реализацию цели, закрепленной ч. 2 ст. 20 Конституции РФ». Введение суда с участием присяжных заседателей на всей территории России не открывает возможность применения смертной казни, в том числе по обвинительному приговору, вынесенному на основании вердикта присяжных заседателей.

Невозможность применения смертной казни, процедура ее назначения и исполнения были установлены и в Постановлении КС РФ от 19.04.2010 г. № 8-П: «в контексте действующего правового регулирования положения федерального законодательства о смертной казни как вида уголовного наказания, процедурах его назначения и исполнения в настоящее время применяться не могут». Однако проблема заключается в том, что КС РФ основывается на нератифицированном Россией Протоколе № 6. 
Несмотря на то, что в России установлен запрет на применение смертной казни, она до сих пор не изъята из федерального законодательства и является одним из видов уголовного наказания (п. 2 ст. 20 Конституции РФ, п. «Н» ст. 44, ч. 1 ст. 45, ст. 59 УК РФ). Возможность применения смертной казни как исключительной меры наказания предусмотрена в пяти статьях УК РФ: ч. 2 ст. 105, ст. 277; ст. 295, ст. 317, ст. 357.

Статьи 31, 51, 301, 310 УПК РФ также содержат положения о смертной казни, а ст. 123 УИК РФ регламентирует порядок исполнения наказания в виде смертной казни.

Федеральным закономот17.12.2009г. №324-Ф3 в ст. 59 УК РФ внесены изменения, согласно которым законодатель фактически признал существование смертной казни как вида уголовного наказания, что создает возможность для возврата к ее применению и исполнению.

На наш взгляд, поскольку смертная казнь несовместима с принятыми международно-правовыми стандартами в области защиты прав человека и исключает возможность исправления судебной ошибки при исполнении обвинительного приговора, поскольку неотъемлемым условием приглашения в Совет Европы явилось намерение России подписать в течение одного года и ратифицировать не позднее чем через три года после вступления в Совет Европы Протокол № 6 к Конвенции, а также установить мораторий на исполнение смертных приговоров, следовательно, указанные обстоятельства свидетельствуют о принятии Россией международных обязательств, касающихся отмены смертной казни в мирное время.

Согласно ст. 18 Венской конвенции о праве международных договоров, если государство подписало договор, подлежащий ратификации, но его не ратифицировало и вместе с тем не заявило о том, что принято решение не ратифицировать подписанный договор, оно должно вести себя так, чтобы это не противоречило данному договору.

Таким образом, подписав, но не ратифицировав Протокол № 6, Россия приняла на себя международные обязательства по отмене смертной казни, что не исключает выполнения обязанности по ратификации указанного Протокола.

В условиях, когда законодатель устранился от выполнения обязательства страны по ратификации 6-го Протокола, КС РФ принял решения, в которых установил запрет на назначение наказания в виде смертной казни, по существу подменив функцию законодательной власти. Как справедливо заметил Э. $Ф$. Побегайло, КС РФ «вынес не правовое, а политическое решение при игнорировании мне- ния абсолютного большинства российских граждан» 23 .

Еще в 1999 г. КС РФ принял постановление, в котором установил запрет на назначение наказания в виде смертной казни и исполнение ранее вынесенных приговоров, а Определением от 19.11.2009 г. КС РФ подтвердил запрет на назначение смертной казни.

Правовая позиция, рассматривающая не ратифицированный Протокол № 6 к Конвенции в качестве оснований недопустимости применения уголовного наказания в виде смертной казни, содержится и в других определениях КС РФ24.

На наш взгляд, основные правовые коллизии, связанные с установлением КС РФ запрета на назначение наказания в виде смертной казни, состоят в следующем.

Во-первых, необходимость ратификации международных договоров вытекает из п. «г» ст. 106 Конституции РФ, устанавливающей обязательность рассмотрения в Совете Федерации принятых Госдумой федеральных законов по вопросам ратификации международных договоров.

Кроме того, согласно ст.ст. 14, 15 Федерального закона «О международных договорах РФ» ратификация международных договоров осуществляется в форме федерального закона. Ратификации подлежат международные договоры России, предметом которых являются основные права и свободы человека и гражданина.

Таким образом, ратификация международных договоров, в том числе и протоколов к ним, осуществляется исключительно в форме федерального закона, принимаемого Госдумой с обязательным его рассмотрением и одобрением в Совете Федерации, а не в форме решений КС РФ.

В-вторых, нератифицированный Протокол № 6 не может являться непосредственно действующим, поскольку его нормы противоречат российскому законодательству. Кроме того, предметом правового регулирования Протокола № 6 являются основные права и свободы человека и гражданина, а с учетом требований законодательства он подлежит обязательной ратификации в форме федерального закона.

23 Побегайло Э. Ф. О преступности в России и проблеме смертной казни // Вестник Московского университета. Серия 18 «Социология и политология». 2010. № 3. С. 29.

24 Определения Конституционного Суда РФ от 17.10.2006 г. № 434-О; от 15.05.2007 г. № 380-О-О; от 16.10.2007 г. № 682-О-О; от 16.10.2007 г. № 684-О-О; от 16.10 .2007 г. № 686-О-О; от 16.10.2007 г. № 689-О-О; Определение Конституционного Суда РФ от 16.10.2007 г. № 692-О-О; от 16.10 .2007 г. № 712-О-О; от 18.12.2007 г. № 935-О-О; от 18.12.2007 г. № 943-О-О; от 24.01.2008 г. № 54-O-O // base.consultant.ru. 
В-третьих, аргументация КС РФ, изложенная в Определении от 19.11.2009 г. № 1344-О-Р, представляется весьма спорной по следующим основаниям:

1. Со стороны КС РФ совершенно проигнорирован тот факт, что Протокол № 6 , внесенный в Госдуму РФ еще о6.08.1999 г., до сих пор ею не рассмотрен и не ратифицирован и, следовательно, для России он формально не имеет юридической силы ${ }^{25}$.

2. Согласно п. 4.3 Определения КС РФ от 19.11.2009 г. № 1344-О-Р «тот факт, что Протокол № 6 до сих пор не ратифицирован, в контексте сложившихся правовых реалий не препятствует признанию его существенным элементом правового регулирования права на жизнь».

В связи с этим возникает вопрос: как нератифицированный международный документ может являться существенным элементом правового регулирования права на жизнь в России?

На наш взгляд, нератифицированный международный документ не может рассматриваться в качестве нормативного акта, непосредственно отменяющего в России смертную казнь в смысле ч. 2 ст. 20 Конституции РФ. Кроме того, в действующем законодательстве сохраняются положения, предусматривающие смертную казнь как вид уголовного наказания, а также процедуры ее назначения и исполнения.

3. КС РФ указал, что «поскольку Протокол № 6 до сих пор не ратифицирован, он как таковой не может рассматриваться в качестве нормативного правового акта, непосредственно отменяющего в России смертную казнь в смысле ч. 2 ст. 20 Конституции РФ. При этом в федеральном законодательстве сохраняются положения, предусматривающие данный вид наказания и, соответственно, процедуры его назначения и исполнения» (п. 6 Определения КС РФ от 19.11.2009 г. № 1344-О-Р).

В то же время КС РФ, вступая в противоречие с указанной констатацией, признает, что нератифицированный Протокол № 6 не может рассматриваться в качестве нормативного правового акта, непосредственно отменяющего в России смертную казнь.

4. Трудно согласиться с правовой позицией КС РФ, согласно которой «в России действует конкретизирующий закрепленные Конституцией РФ гарантии права на жизнь комплексный мораторий на применение смертной казни», «происходит необратимый процесс, направленный на отмену смертной казни» (пп. 6, 7 Определения КС РФ от 19.11.2009 г. № 1344-О-Р). На наш взгляд, невыполнение Россией принятых на себя международных обязательств по ра-

25 Быков В. М. Имел ли право Конституционный Суд РФ приостановить действие Конституции РФ? // Российский судья. 2010. № 3. С. 36. тификации Протокола № 6 как раз свидетельствует об обратном.

Фактически же КС РФ не отменил, а в очередной раз продлил им же ранее объявленный мораторий на применение смертной казни.

В-четвертых, КС РФ отметил, что установленный запрет применения смертной казни не затрагивает прерогативы Федерального Собрания в отношении ратификации Протокола № 6 (п. 7 Определения КС РФ от 19.11.2009 г. № 1344-О-Р). Между тем такая оговорка не имеет существенного значения, поскольку, констатируя установление запрета на применение смертной казни, КС РФ подменил собой законодателя.

В-пятых, установленный КС РФ мораторий на применение смертной казни противоречит законодательству, которым не предусмотрено объявление моратория; КС РФ не вправе приостанавливать действие федерального законодательства и устанавливать какой-либо мораторий; смертная казнь предусмотрена Конституцией РФ, поэтому в государстве, провозгласившем себя демократическим и правовым, где закреплены принципы разделения властей и верховенство Конституции РФ, недопустимо решать вопрос об отмене данного наказания на основании лишь временной меры, установленной КС РФ, а не законодателем.

Принимая во внимание ключевые аспекты проблемы, отметим, что принятое КС РФ решение с юридической точки зрения далеко не безупречно. Его законность вызывает сомнение, поскольку он вышел за пределы своих полномочий и вторгся в сферу компетенции законодателя.

В-шестых, принятые Россией действия направлены на установление запрета на применение смертной казни (т. н. «моратория»), но не на выполнение принятых международных обязательств, выражающихся в абсолютном отказе от смертной казни и в исключении смертной казни как вида уголовного наказания из федерального законодательства. Следовательно, в сложившейся ситуации решение вопроса о смертной казни в России находится не в правовой, а в политической плоскости.

Вся эта ситуация вызывает удивление, поскольку вместо того, чтобы выполнить принятые международные обязательства, законодательство РФ до сих пор не приведено в соответствие с европейскими нормами в области прав человека, не ратифицирован Протокол № 6 и не внесены изменения в законодательство, направленные на отмену смертной казни.

Полагаем, что только ратификация Россией Протокола № 6, а также исключение смертной казни из законодательства могут стать свидетельством выполнения принятых на себя Россией международных обязательств и движения 
в направлении абсолютной отмены смертной казни.

Вышеизложенное подводит нас к следующим выводам:

1. Парламент России уклоняется от выполнения принятых Россией при вступлении в Совет Европы международных обязательств, в результате чего наша страна является единственным государством - членом Совета Европы, не ратифицировавшим Протокол № 6 к Конвенции о защите прав человека и основных свобод.

2. Протокол № 6 не может рассматриваться в качестве нормативного акта, непосредственно отменяющего смертную казнь, поскольку он не ратифицирован Россией.

3. В российском законодательстве сохраняются положения, предусматривающие смертную казнь как вид уголовного наказания, а также процедуры ее назначения и исполнения, поэтому отсутствуют надлежащие гарантии неприменения смертной казни.

4. Россией не только не ратифицирован Протокол № 6, но также не подписаны и не ратифицированы Протокол № 13 об отмене смертной казни при любых обстоятельствах и Второй Факультативный протокол к Международному пакту о гражданских и политических правах, что не может свидетельствовать о ее намерении отказаться от применения смертной казни.

С целью реализации принятых Россией международных обязательств, направленных на отмену смертной казни, необходимо:

1. Ратифицировать Протокол № 6 к Конвенции о защите прав человека и основных свобод.

2. Подписать и ратифицировать Протокол № 13 к Конвенции о защите прав человека и основных свобод, а также Второй Факультативный протокол к Международному пакту о гражданских и политических правах.

3. Внести изменения в действующее законодательство (Конституция РФ, УК РФ, УПК РФ, УИК РФ), направленные на исключение положений о применении смертной казни.

\section{Список литературы}

1. Berns W. For Capital Punishment: Crime and the Morality of the Death Penalty. N.Y.: Basic Books, 1979. P. 322.

2. Агаев Д. О. Современные тенденции развития института смертной казни // Пробелы в российском законодательстве. 2012. № 1. С. 156-158.

3. Быков В. М. Имел ли право Конституционный Суд РФ приостановить действие Конституции РФ? // Российский судья. 2010. № 3. С. 33-36.

4. Дворецкий М. Ю. Уголовная ответственность в отечественном законодательстве в контексте эффективности реализации: проблемы теории и практики применения // Российский журнал правовых исследований. 2014. № 2 (3). С. 181-186

5. Квашис В. Е. Смертная казнь. Мировые тенденции, проблемы и перспективы. М.: Юрайт, 2008. 800 с.
6. Коновалова Т. Ф. Нужна ли России смертная казнь? // Уголовно-исполнительная система: право, экономика, управление. 2010. № 2. С. 23-25.

7. Коняев С. А. Мораторий на применение смертной казни в России: конституционно-правовой аспект // Вестник Воронежского государственного университета. Серия «Право». 2011. № 1. С. 70-78.

8. Кудрявцев В. Н. Стратегии борьбы с преступностью. М.: Наука, 2005. 366 с.

9. Малько А. В., Терехин В. А., Афанасьев С. Ф. Смертная казнь в современной России: не пора ли наконец определиться? // Криминологический журнал БГУЭП. 2014. № 2. С. 79-89.

10. Назарова Ф. На пути к отмене смертной казни опыт СНГ и Европейского Союза. Душанбе, 2010.

11. Павликов С. Г., Флейшер Н. Б. К вопросу о судебных ошибках // Российский журнал правовых исследований. 2015. № 1 (2). С. 203-209.

12. Побегайло Э. Ф. О преступности в России и проблеме смертной казни // Вестник Московского университета. Серия 18 «Социология и политология». 2010. № 3. С. 24-39.

13. Работа судов общей юрисдикции в 1999 году // Российская юстиция. 2000. № 7, 8 .

14. Работа судов общей юрисдикции в 2000 году // Российская юстиция. 2001. № 11.

15. Сергеевский Н. Д. Лишение жизни как уголовное наказание // Юридический вестник. 1879. № 6. C. $848-857$.

16. Сидоркин А. С. Проблема отмены смертной казни сквозь призму общих принципов права // Вестник РУДН. Серия «Юридические науки». 2010. № 4. C. 27-34.

17. Соловьев В. С. Оправдание добра: нравственная философия. М.: Республика, 1996. 478 с.

18. Степенко А. В., Никулина О. А. Исключительные случаи применения смертной казни // Ученые заметки ТОГУ. 2014. Т. 5. № 4. С. 404-407.

19. L.C.В. против Соединенного Королевства: Постановление ЕСПЧ от 09.06.1998 г. // http://www.echr. coe.int.

20. Осман (Osman) против Соединенного Королевства: Постановление ЕСПЧ от 28.10.1998 г. // http://www. echr.coe.int.

21. Кипр против Турции: Постановление ЕСПЧ от 10.05.2001 г. // http://www.echr.coe.int.

22. Макаратзис (Makaratzis) против Греции: Постановление ЕСПЧ от 20.12.2004 г. // http://www.echr. coe.int.

23. Постановление Московского городского суда от 05.08.1999 г. по обвинению П. А., Л. Р., Г. В., Ш. А., А. А., Б. М., Т. И., С. С., М. А. и др. // base.consultant.ru.

24. Постановление Московского городского суда от 11.08.1999 г. по обвинению Г. А. // base.consultant.ru. 


\title{
The problem of the legislative sentence to the death penalty in russia in the context of international obligations
}

\author{
Ivanov A. V., \\ lawyer \\ (Krasnodar Regional Advocates' Collegium) \\ Kostylev Str., 27, Krasnodar 350000 \\ e-mail: advocatkk@gmail.com
}

\begin{abstract}
Legislative Sentence to the death penalty as an exceptional measure of capital punishment and its relation to the right to life have been a subject of public discussion for a long time, and nowadays they are topical ones for every civilized state.

The International law prohibits the use of capital punishment by a country because the death penalty is the ultimate cruel, inhuman and degrading punishment as well as because the legislative Sentence to the death penalty is contrary to the basic principle of respect for human rights and fundamental freedoms including the recognition of an absolute right to human life.

One of the essential conditions for invitation of Russia to the Council of Europe has been the legislative Sentence for the abolition of the death penalty, but Russia still has not ratified Protocol No. 6, and has not taken action on the absolute refusal of the death penalty, so the problem of the Sentence to the death penalty as a capital punishment, continues to be topical more than ever.

Keywords: right to life; the death penalty; juristic Sentence to the death penalty; crime; capital punishment; abolition of capital punishment; international obligations; the abolition of the death penalty; moratorium; ratification; Protocol No. 6; Protocol No. 13; the Second optional Protocol to the International Covenant on Civil and Political Rights.
\end{abstract}

\section{References:}

1. Berns W. For Capital Punishment: Crime and the Morality of the Death Penalty. N.Y .: Basic Books, 1979. P. 322.

2. DO Agayev Modern trends of development of the institution of the death penalty / DO Agayev // Gaps in Russian legislation. 2012. № 1. Pp 156-158.

3. Bykov VM Did the right of the Constitutional Court of the Russian Federation to suspend the Constitution of the Russian Federation? // Russian judge. 2010. № 3. Pp. 33-36.

4. Dvoretskiy M. Y. Butler Criminal liability in domestic law in the context of the efficiency of implementation: problems of theory and practice of application // Russian Journal of Legal Studies. 2014. №2 (3). Pp. 181-186

5. Kvashis V. E. The death penalty. Global trends, problems and prospects. M .: Yurayt, 2008. $800 \mathrm{pp}$

6. Konovalov T. F. Does Russia need the death penalty? // Penal system: law, economics, management. 2010. № 2. Pp. 23-25.

7. Konyaev S. A. Moratorium on the death penalty in Russia, constitutional-legal aspect // Herald of the Voronezh State University. Series: Law. 2011. № 1. Pp. 70-78.

8. Kudryavtsev V. N. Strategies to combat crime. M .: Nauka, 2005. 366 p.

9. Malko A. V. Terekhin V. Afanasiev SF The death penalty in modern Russia: is it time to finally decide? // Kriminologichesky Journal BSUEL. 2014. № 2. Pp. 79-89.

10. Nazarov F. Towards abolition of the death penalty - the experience of the CIS and the European Union. Dushanbe, 2010.

11. Pavlikov S. G., Fleischer NB On the issue of judicial errors // Russian Journal of Legal Studies. 2015. №1 (2). Pp. 203-209

12. Pobegailo E. F. About crime in Russia and the death penalty // Bulletin of Moscow University. Series 18. Sociology and Political Science. 2010. № 3. Pp. 24-39.

13. The work of courts of general jurisdiction in 1999 // the Russian justice. 2000. № 7, 8.

14. The work of courts of general jurisdiction in 2000 // the Russian justice. 2001. № 11.

15. Sergeyevsky N. D. The deprivation of life as a criminal offense // Legal Gazette. 1879. № 6. Pp. 848-857.

16. Sidorkin A. S. The problem of the death penalty dumped prism of the general principles of law // Bulletin of Peoples' Friendship University, a series of Jurisprudence. 2010. № 4. Pp. 27-34.

17. Solovyov V. S. Justification of the Good: Moral philosophy. M .: Republic, 1996. 478 pp.

18. Stepenko A. V., Nikulin O. A. Exceptional cases of the death penalty // Scientific notes PNU. 2014. Volume 5. № 4. Pp. 404407.

19. L.C.B. the United Kingdom: Decision of 09.06.1998, the ECtHR // http://www.echr.coe.int.

20. Osman (Osman) against the United Kingdom: Decision of 28.10.1998, the ECtHR // http://www.echr.coe.int.

21. Cyprus against Turkey by the ECtHR Decision of $10.05 .2001 / / \mathrm{http}: / /$ www.echr.coe.int.

22. Makaratzis (Makaratzis) against Greece: ECtHR Decision dated 20.12.2004, the // http://www.echr.coe.int.

23. Resolution of the Moscow City Court on 05.08.1999, the accused P. A., L. R., G. V., Sh. A., A. A., B. M., T. I., S. S., M. A. et al. // base.consultant.ru.

24. Resolution of the Moscow City Court on 11.08.1999, the accused GA // Base.consultant.ru. 